\title{
Factors Affecting Labor Productivity in the Construction Industry
}

\author{
Rabia Almamlook ${ }^{1}$, Mohamed Bzizi ${ }^{2}$, Maha Al-Kbisbeh ${ }^{3}$, Tgarid Ali ${ }^{4}$, Ekbal Almajiri ${ }^{5}$ \\ ${ }^{1}$ Department of Industrial Engineering and Engineering Management, Western Michigan University, Kalamazoo, USA \\ ${ }^{2}$ Department of Business Administration, Western Michigan University, Kalamazoo, USA \\ ${ }^{3}$ Civil and Construction Engineering Department, Western Michigan University, Kalamazoo, USA \\ ${ }^{4}$ Department of Civil and Construction Engineering, UDM, Detroit, USA \\ ${ }^{5}$ Department of Civil Engineering, CU, Colorado, USA
}

Email address:

rabiaemhamedm.almamlook@wmich.edu (R. Almamlook),bzizi14@gmaill.com (M. Bzizi),

maharedaabdel.alkasisbeh@wmich.edu (M. Al-Kbisbeh), alita1@udmercy.edu (T. Ali), ekbalkh1@yahoo.co.uk (E. Almajiri)

\section{To cite this article:}

Rabia Almamlook, Mohamed Bzizi, Maha Al-Kbisbeh, Tgarid Ali, Ekbal Almajiri. Factors Affecting Labor Productivity in the Construction Industry. American Journal of Environmental Science and Engineering. Vol. 4, No. 2, 2020, pp. 24-30.

doi: 10.11648/j.ajese.20200402.13

Received: September 23, 2019; Accepted: November 19, 2019; Published: May 29, 2020

\begin{abstract}
Labor productivity is gaining growing attention as the construction industry faces many challenges related to workforce, but one of the most important is poor labor productivity. Several construction projects were suffering from various problems, including poor management, declining fertility, and thus causing projects delay, and cost overruns. The main goals of this study, therefore, is to identify and rank the factors affecting labor productivity in the construction industry in Libya. To realize this objective, a statistically demonstrative sample of contractors and embassies were demanded to contribute to a structured questionnaire survey. The questionnaire contained 30 productivity factors that were secret under the following three primary categories: (1) Management, (2) Technological, (3) and Human/labor. The Management Group was ranked the first, followed by the Technological and Human/labors group. This study demonstrates that the following five factors, listed in descending order, are the most significant in their effects on construction labor productivity: (1) Lack of labor supervision; (2) Experience and skill of labor; (3) Construction technology; (4) Coordination among construction industry disciplines; (5) Errors in design drawings. The results obtained to fill a gap in knowledge of factors affecting labor productivity in Libya to develop a more in-depth perspective of the factors influencing the efficiency of operatives. This study also has provided some recommendations to be implemented by construction managers at the early stage of the construction project to achieve more effective management of construction labor forces.
\end{abstract}

Keywords: Labor Productivity, Relative Importance Index, Rank, Construction Industry of Libya

\section{Introduction}

The construction industry is a strategic industry to the national economy, providing an organization and accommodation for other economic activities to take place. Attar (2012) indicated that construction is a vital sector of the national economy for all countries around the world. It revenues up an important serving of the nation's total employment and its significant contribution to a nation's revenue as a whole. Yates and McTague noted that in most of the construction projects, labor costs account for between 30 and $50 \%$ of a project's total cost [28-21]. Therefore, this is observed as an accurate replication of the economic success of the operation. Liu showed that labor productivity had played a critical role in influencing the financial success of the project [18].

The decrease of labor and then, construction costs can be best approved out by labor productivity development. Productivity is the key to greater competitiveness, as it is critical to the profitability of most construction projects. Besides, according to Frefer; productivity is one of the essential aspects of the erection industry, which helps its 
survival and growth [11]. Wilcox argued that improving productivity is a crucial concern for any profit-oriented association and effective change of resources into marketable products, and it determines business productivity [27]. In the situation of construction, labor productivity has become a big problem in the construction industry. The construction industry faces many challenges in Libya, but one of the most significant challenges is low productivity in construction.

This paper examines factors that perceived to affect construction labor productivity in Libyan construction sites concerning identify. The outcomes can be used by not only local but international industry consultants, who may be interested further in super-scale projects. It guides projects and construction managers for efficient application of the labor force, thus assist in achieving a reasonable level of competitiveness and money-making operation.

\section{Literature Review}

Total factor productivity is defined as the ratio of outputs to inputs and as shown in Eq. (1):

$$
\text { Total Productivity }=\frac{\text { Output }}{\text { Input }}
$$

All input resources may include but are not limited to, labor, material, energy, capital, and design. Overall productivity is a comprehensive measure that accounts for all outputs and inputs. Partial factor productivity establishes a relationship between outputs and a single or selected set of data. The definition is best illustrated by the term labor productivity, where only the input of labor is considered. Other individual or partial factor productivity measures include capital, employment, and equipment productivity. Therefore, PFP can be defined as shown in Eqs. (2), (3), (4).

$$
\text { Average Labour productiveely }=\frac{\text { Output }}{\text { labour Employed }}
$$

$$
\begin{aligned}
& \text { Average capital productively }=\frac{\text { profit }}{\text { Capital Invested }} \\
& \text { Equipment plan productivity }=\frac{\text { Output quatity }}{\text { equipmet }}
\end{aligned}
$$

The literature has identified several factors that were explored in this study. The factors that influence construction productivity have been the subject of inquiry by many researchers. Making use of the factors that have a positive effect and controlling factors that have a negative impact will improve productivity. It would also be possible to predict labor productivity if all factors influencing productivity are known [16]. Table 1 presents a summary of the lists of many different factors affecting labor productivity reported by many researchers in the literature. In this study, the researchers proposed the following three primary groups as the basis for categorizing the identified various corresponding factors affecting the labor productivity in the construction industry in Libya: namely; (1) management group; (2) technological group and (3) human/labor group.

\section{Research Methodology}

Data were collected based on questionnaires and interviews. The present study uses the method for data collecting: (1) Expert interviews. (2) Questionnaire. (3) Literature review. The design viewpoint of the survey was that the questions had to be simple, clear, and understandable for the respondents and able to be precisely understood by the investigator. Factors affecting the productivity of construction labor were identified based on previous literature, with participation, review, and adjustments by local experts; a total of 30 elements were recognized. The experts were required to rank the factors affecting construction labor productivity, considering time, cost, and

\begin{tabular}{|c|c|c|}
\hline Country & Reference & Labor Productivity Factors \\
\hline Nigeria & (Olomolaiye 1987) & $\begin{array}{l}\text { Lack of materials; inadequate tools; work repetition; inspection delays; instruction delays; supervisors' } \\
\text { incompetence; absenteeism and changing crew members. }\end{array}$ \\
\hline UK & (Horner 1989) & $\begin{array}{l}\text { Skill of labor; buildability; quality of supervision; method of working; incentive scheme; site layout; complexity of } \\
\text { construction information; crew size and composition; length of working day; availability of power tools; } \\
\text { absenteeism; total number of operatives on site; proportion of work subcontracted. }\end{array}$ \\
\hline Singapore & (Lim 1995) & $\begin{array}{l}\text { Difficulty in recruitment supervisors; difficulty in recruiting workers; high rate of labor turnover; absenteeism at } \\
\text { work site; communication problems with foreign workers; inclement weather that requires work stoppage for one } \\
\text { day or more. }\end{array}$ \\
\hline Iran & (Zakeri 1996) & $\begin{array}{l}\text { Material shortage; weather and site conditions; equipment breakdown; drawing deficiencies/change orders; lack of } \\
\text { proper tools and equipment }\end{array}$ \\
\hline Indonesia & (Olomolaiye 1996) & Lack of materials; rework; absenteeism of operatives; lack of suitable tools and equipment; crew interference. \\
\hline Malaysia & $\begin{array}{l}\text { (Abdul Kadir } \\
\text { 2005) }\end{array}$ & $\begin{array}{l}\text { Material shortage at site; non-payment to suppliers, causing the stoppage of material delivery to site; change orders } \\
\text { by consultants; late issuance of construction drawings by consultants; incapability of the contractors' site } \\
\text { management to organize site activities. }\end{array}$ \\
\hline Uganda & (Alinaitwe 2007) & $\begin{array}{l}\text { Incompetent supervisors; lack of skills among the workers; rework; lack of tools/ equipment; poor construction } \\
\text { methods; poor communication; stoppages because of work being rejected by consultants; political insecurity; } \\
\text { tools/equipment breakdown; harsh weather conditions. }\end{array}$ \\
\hline Gaza Strip & (Enshassi 2007) & $\begin{array}{l}\text { Material shortage; lack of labor experience; lack of labor surveillance; misunderstanding between labor and } \\
\text { superintendents; alteration of drawings and specifications during execution. }\end{array}$ \\
\hline New Zealand & (Durdyev 2011) & $\begin{array}{l}\text { Reworks; level of skill and experience of the workforce; adequacy of method of construction; buildability issues; } \\
\text { inadequate supervision and coordination; statutory compliance; unforeseen events; wider external dynamics. }\end{array}$ \\
\hline
\end{tabular}
quality using their knowledge and experiences on project constructions Frefer [9, 10].

Table 1. Summary of the various factors affecting labor productivity that was reported in previous studies and references of these studies. 


\begin{tabular}{|c|c|c|}
\hline Country & Reference & Labor Productivity Factors \\
\hline Kuwait & (Jarkas 2012) & $\begin{array}{l}\text { Clarity of technical specifications; extent of variation/change orders during execution; coordination level among } \\
\text { various design disciplines; lack of labor supervision; proportion of work subcontracted. }\end{array}$ \\
\hline Palestine & (Mahamid 2013) & $\begin{array}{l}\text { Political situation, equipment's shortages, old and inefficient equipment, lack of labor experience, poor site } \\
\text { management, poor communication and coordination between construction parties, payments delay by the owner, } \\
\text { low wages, rework, and misuse of time schedule. }\end{array}$ \\
\hline Egypt & (El-Gohary 2014) & $\begin{array}{l}\text { Labor experience and skills; incentive programs; availability of the material and ease of handling; leadership and } \\
\text { competency of construction management; competency of labor supervision; construction technology (construction } \\
\text { method and material); labor operating system (daily wage, lump sum); planning, work flow, and site congestion; } \\
\text { constructability (integrated design and construction) and clarity of instructions }\end{array}$ \\
\hline Indian & (Anu 2014) & $\begin{array}{l}\text { Timely availability of materials, delayed material delivery by the supplier, strikes called by political parties, } \\
\text { frequent revisions of design, resulting in additional rework, and unavailability of drawings at the worksite at the } \\
\text { required time, poor project planning and scheduling, improper project. }\end{array}$ \\
\hline Jordan & (Bekr 2016) & $\begin{array}{l}\text { Poor planning and scheduling, material shortage at project site, equipment and tools shortage, lack of skilled labor, } \\
\text { poor site management, rework due to construction errors, old and inefficient equipment, lack of supervisor's } \\
\text { experience, payment delay to suppliers and slow response of consulting staff inspecting the work. }\end{array}$ \\
\hline Vietnamese & (Tam, 2018) & $\begin{array}{l}\text { Employee experience; labour discipline; pay forms; quality of construction materials; ability to organize } \\
\text { production; quality of tools and tools; organization of construction supervision; strength and heights }\end{array}$ \\
\hline
\end{tabular}

\subsection{Date Collection}

The survey presents 30 productivity factors generated on the basis of related research works on construction productivity [28-17-16-22-26-23-20-1-14], together with input, revision, and modifications by local experts. These factors were classified into three groups based on previous literature and advice by local experts: management-related factors, technology-related factors, and human/labors related factors. The targeted population for the survey includes contractors who hold valid registration from the Libyan Union for Construction \& Building Contractors. A systematic random sampling was selected to ensure the representative sample of all contractors by using Eq. (4) (Hogg 2009):

$$
\mathrm{n}=\frac{m}{1+\frac{m-1}{\mathrm{~N}}}
$$

where $\mathrm{n}, \mathrm{m}$, and $\mathrm{N}=$ sample sizes of the limited, unlimited, and available the population, respectively. On the other hand, $\mathrm{m}$ is estimated by Eq. (5):

$$
\mathrm{m}=\frac{\mathrm{z}^{2} * p *(1-\mathrm{p})}{\varepsilon^{2}}
$$

$\mathrm{z}=$ statistical value for the confidence level used, i.e., $1.645,1.96$, and 2.57 , for 90,95 , and $99 \%$ confidence levels, respectively; $\mathrm{P}=$ degree of variance between the elements of population; and $\varepsilon=$ maximum error of the point estimate.

Since the value of $p$ is unknown, Sincich suggest a typical value of 0.50 be used so that a sample size that is at least as large as required to be obtained [24]. By using a 95\% confidence level, i.e., a 5\% significance level, the unlimited sample size of the population, $\mathrm{m}$, is approximated as follows:

$$
\mathrm{m}=\frac{(1.96)^{2} *(0.50) *(1-0.50)}{(0.05)^{2}}=385
$$

Consequently, for the total number of classified contractors under the first, second, and third categories, i.e., N, of 230, the representative sample size of the population required, is determined as shown below:

$$
\mathrm{n}=\frac{385}{1+\frac{385-1}{120}}=92
$$

A total of 92 questionnaires were completed by contractors, consultants, managers, and experienced engineers. The overall response to the survey comprised a total of 76 completed questionnaires, representing approx. $82 \%$ response rate. The results have been achieved by continuous following-up and close personal contact with contractors.

\subsection{Date Analysis Approach and Questionnaire Design}

The data collected were investigated using the Relative Importance Index (RII) technique [8-17-15]: The formula shown in Eq calculated the Relative Importance Index \% for each factor explored. (8):

$$
\mathrm{RII}=\frac{5(\mathrm{n} 5)+4(\mathrm{n} 4)+3(\mathrm{n} 3)+2(\mathrm{n} 2)+\mathrm{n} 1}{5(\mathrm{n} 1+\mathrm{n} 2+\mathrm{n} 3+\mathrm{n} 4+\mathrm{n} 5)} \times 100
$$

Where $n 1, n 2, n 3, n 4$, and $n 5$ are the number of respondents, who selected: 1, for no effect; 2, for little impact; 3, for moderate impact; 4, for strong implications; and 5, for powerful influence, respectively. The RII, which ranges from 0 (not inclusive) to 1.00 , was used to determine the rank of each factor investigated; the higher the RII value, the stronger the perceived effect of the motivational factor on master craftsmen's productivity.

\section{Results and Discussion}

In this study, 30 factors affecting labor productivity in building construction of Libya have been identified and rated according to their relative importance. The elements are classified into three major categories as follows: sixteen under the Management category; three under the Human category; and eleven under the Technological category. The relative importance indices, rank within the corresponding group, and the overall ranks of the factors investigated are discussed and related to the previous related findings reported in the literature. The RII was used to determine the 
influence each element has on construction projects with the highest value attained in the index, indicating the highest rank.

\subsection{Ranking of Management Factors}

Table 2 presents the findings of the perceived importance of factors classified under this group. With a relative importance index of $87.6 \%$, the clarity of lack of labor supervision factor ranks the first not only in this group but also among the 30 factors explored. They are thus considered the most significant factor affecting construction labor productivity in Libya. As shown in (Table 5), experience and skill of labor were also ranked the second among all 30 factors with negatively affecting labor productivity. It indicates a lack of labor experience has a very high effect on productivity. This result is supported by Abdul Kadir; who found that the skill of the craftsmen affects labor productivity [1].

The lack of incentive scheme, which is ranked second in this group with a relative importance index of $80.9 \%$, and eighth among all factors explored. Thus, a monetary incentive scheme further promotes the objective of operatives and creates a high level of motivation and satisfaction among them; as a result, higher efficiency is achieved on site. With a relative importance index of $80.2 \%$, the Working overtime factor is ranked the third in this group and ninth compared to all other factors surveyed. This finding agrees with the outcomes of Horner and Soham, whose investigation classified this factor among the crucial determinants of labor productivity in the South Gujarat region of India, respectively [13-25].

Lack of construction manager's leadership, with a relative importance index of $77.2 \%$ is ranked the fourth within the management group and the eighth among other factors. The fifth-ranked factor, Payment delay with a relative importance index of $77 \%$, is further ranked the eleventh among the factors surveyed. The sixth-ranked factor, Unavailability of materials, with a relative importance index of $76.1 \%$, is further ranked the twelfth among the factors surveyed. Therefore, work cannot progress or be accomplished without it; it was listed as the sixth factor of affect productivity of the construction industry in Libya. With a relative importance index of $74.2 \%$, the Construction method is ranked the seventh within this group, and fourteenth among all factors investigated.

Table 2. RII Ranking of Management.

\begin{tabular}{lll}
\hline Factors & RII & Rank \\
\hline Lack of labor supervision & 0.876 & 1 \\
Lack of incentive scheme & 0.809 & 2 \\
Working overtime & 0.802 & 3 \\
Construction manager's lack of leadership & 0.772 & 4 \\
Payment delay & 0.770 & 5 \\
Unavailability of materials & 0.761 & 6 \\
Construction method & 0.742 & 7 \\
Lack of providing labor with transportation & 0.729 & 8 \\
Incompetent supervisors & 0.662 & 9 \\
Accidents because of poor safety & 0.603 & 10 \\
\hline
\end{tabular}

\begin{tabular}{lll}
\hline Factors & RII & Rank \\
\hline $\begin{array}{l}\text { Unsuitability of storage location } \\
\begin{array}{l}\text { Communication problems between site management } \\
\text { and labor }\end{array}\end{array}$ & 0.576 & 11 \\
$\begin{array}{l}\text { Late-arrival, early quit, and frequent unscheduled } \\
\text { breaks }\end{array}$ & 0.556 & 12 \\
Lack of training offered to operatives & 0.527 & 13 \\
$\begin{array}{l}\text { Lack of recognition program } \\
\text { Unavailability of equipment and suitable tools }\end{array}$ & 0.510 & 14 \\
\hline
\end{tabular}

The other significant factors which have less effect on productivity are: Incompetent supervisors, Accidents because of poor safety, Unsuitability of storage location, Communication problems between site management and labor, Late-arrival, early quit, \& frequent unscheduled breaks, Lack of training offered to operatives, Lack of recognition program, and Unavailability of equipment and suitable tools.

\subsection{Ranking of Human/Labor Factors}

Three classified factors under the human/labor category are identified and ranked, as shown in Figure 1 and Table 1. With a relative importance index of $87.3 \%$, experience and skill of labor are ranked first in this group and second among all factors investigated as shown in Table 5. The result of this study is supported by the findings reported by Alinaitwe in Uganda [2]. Lim in Singapore, which can be considered as a measure of the level of workers' expertise, specialization, and supervisory capability and is essential to the productivity of the construction process [17].

Table 3. RII Ranking of human/labor Factors.

\begin{tabular}{lll}
\hline Factors & RII & Rank \\
\hline Labor motivation & 0.481 & 3 \\
Physical fatigue labor & 0.652 & 2 \\
Experience and skills of labor & 0.873 & 1 \\
\hline
\end{tabular}

Perceiving labor skills as the noticeable factor affecting the efficiency of construction operatives in Libya and indicates a shortage of experienced labor, which further suggests a problem with the quality of the labor force employed in the Libyan's construction industry. Physical fatigue of worker with a relative importance index of $65.2 \%$ is ranked second among the group surveyed and the eighteenth compared with other factors studied.

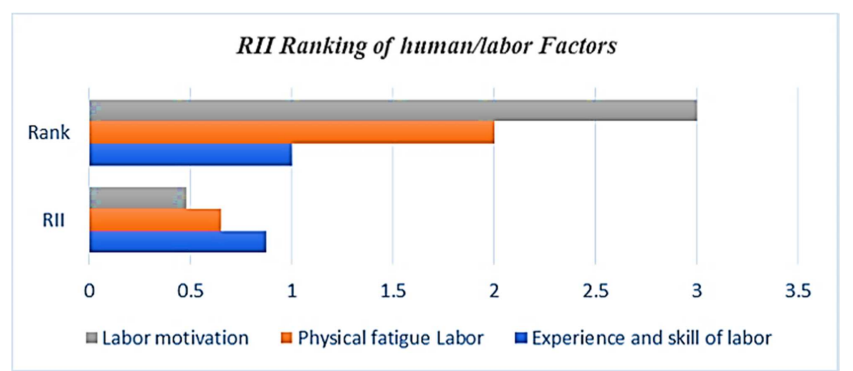

Figure 1. RII Ranking of human/labor Factors.

Labor motivation, which is ranked third in this group with a relative importance index of $48.1 \%$, and 29 th among all 
factors explored.

\subsection{Ranking of Technological Factors}

Durdyev found that the most significant factor related to construction technology affecting the productivity of construction labor is the adequacy of the method of construction [6]. Coordination among design disciplines factor ranked the second in the technology category and fourth among all 30 surveyed elements, with RII of $86.3 \%$. This is also supported by findings obtained by Jarkas in Bahrain [14]. The Errors in design drawings factor ranked third within this group and fifth overall, with RII of $84.5 \%$. Delay in responding to requests for information, with a relative importance index of $83.1 \%$ is ranked the fourth within the technological group. The sixth compared with the overall surveys, while Rework with the index of $82.3 \%$ is ranked the fifth in the group and the seventh among 30 factors constraining labor productivity.

Table 4. RII Ranking of Technological Factors.

\begin{tabular}{lll}
\hline Factors & RII & Rank \\
\hline Construction technology & 0.870 & 1 \\
Coordination among design disciplines & 0.863 & 2 \\
Errors in design drawings & 0.845 & 3 \\
Delay in responding to requests for information & 0.831 & 4 \\
Rework & 0.823 & 5 \\
Inspection delay by the engineer & 0.753 & 6 \\
Quality of drawings & 0.672 & 7 \\
Frequent change to orders during execution & 0.628 & 8 \\
Design complexity & 0.562 & 9 \\
Clarity of technical specifications & 0.546 & 10 \\
Crew size and composition & 0.521 & 11 \\
\hline
\end{tabular}

This result agrees with the findings of Hinze, who argue that the delays and costs associated with Rework in construction have profound impact on productivity [12]. Inspection delay by the engineer is ranked the sixth. This constraint is very significant in terms of its influence on the labor productivity of Libya. Moreover, factor inspection by the engineer is ranked the sixth within a group with RII of $75.3 \%$. The thirteenth of the overall ranks of productivity factors surveyed. However, Quality of drawings and Frequent change to orders during execution are ranked the seventh and eighth within the group with RII of $67.2 \%$ and $62.8 \%$, factors. Sixteenth and nineteenth in terms of the overall elements, respectively.

\subsection{Overall Ranking of the Factors Affecting Construction Labor Productivity in Libya}

Table 5 As shown, the top 10 ranked factors affecting the productivity and efficiency of operatives are as follows: (1) Lack of labor supervision; (2) experience and skill of labor; (3) Construction technology; (4) Coordination among design disciplines; (5) Errors in design drawings; (6) Delay in responding to requests for information; (7) Rework; (8) Lack of incentive scheme; (9) Working overtime; and (10) Construction manager's lack of leadership. It is an interesting finding that, out of the top 10 ranking factors, six are perceived to be directly related to and caused by designers and engineers.

Table 5. Overall Relative Importance Indices and Ranks of Productivity Factors Surveyed.

\begin{tabular}{lll}
\hline Factors & RII & Rank \\
\hline Lack of labor supervision & 0.876 & 1 \\
Experience and skill of labor & 0.873 & 2 \\
Construction technology & 0.870 & 3 \\
Coordination among design disciplines & 0.863 & 4 \\
Errors in design drawings & 0.845 & 5 \\
Delay in responding to requests for information & 0.831 & 6 \\
Rework & 0.823 & 7 \\
Lack of incentive scheme & 0.809 & 8 \\
Working overtime & 0.802 & 9 \\
Construction manager's lack of leadership & 0.772 & 10 \\
Payment delay & 0.770 & 11 \\
Unavailability of materials & 0.761 & 12 \\
Inspection delay by the engineer & 0.753 & 13 \\
Construction method & 0.742 & 14 \\
Lack of providing labor with transportation & 0.729 & 15 \\
Quality of drawings & 0.672 & 16 \\
Incompetent supervisors & 0.662 & 17 \\
Physical fatigue Labor & 0.652 & 18 \\
Frequent change to orders during execution & 0.628 & 19 \\
Accidents because of poor safety & 0.603 & 20 \\
Unsuitability of storage location & 0.576 & 21 \\
Design complexity & 0.562 & 22 \\
Communication problems between site management & 0.556 & 23 \\
and labor & 0.546 & 24 \\
Clarity of technical specifications & 0.538 & 25 \\
Late arrival, early quit, and frequent unscheduled & 0.527 & 26 \\
breaks & 0.521 & 27 \\
Lack of training offered to operatives & 0.510 & 28 \\
Crew size and composition & 0.481 & 29 \\
Lack of recognition program & 0.480 & 30 \\
\hline labor motivation & & \\
Unavailability of equipment and suitable tools & & \\
\hline & & \\
\hline
\end{tabular}

\subsection{Overall Ranking of Categories Factors Affecting Construction Labor Productivity}

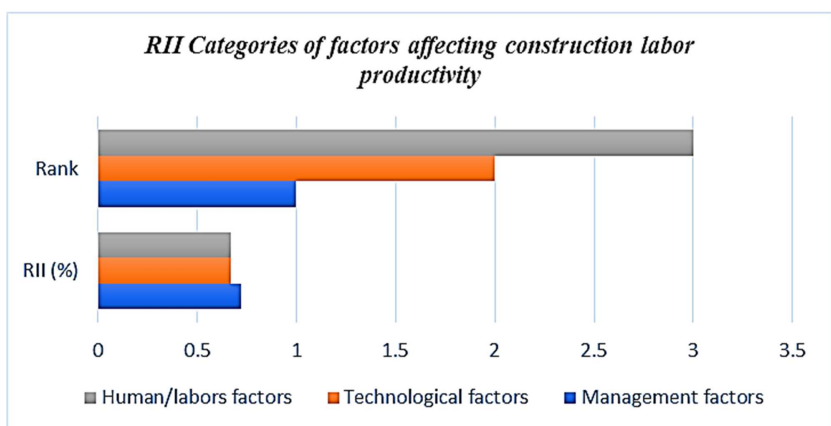

Figure 2. RII Categories of factors affecting construction labor productivity.

Figure 2 shows the overall ranking of the three primary groups, under which the corresponding factors affecting labor productivity are classified. The results obtained demonstrate that the Management group is ranked first with the highest average RII score of $71.9 \%$. This is followed closely by technological factors group, ranked second with an average RII score of $67 \%$. The Human/labors group is ranked third with an overall average RII score of $66.8 \%$. 


\section{Conclusions and Recommendations for Further Research}

This study has identified the factors that affected on labor productivity within the Libya construction industry. A total of 30 factors were identified in this study, with an identification of factors influencing construction productivity which is based on a careful review of literature and suggestions from local experts in building construction. The results indicate that 10 main top factors negatively affecting labor productivity, which are: (1) Lack of labor supervision; (2) experience and skill of labor; (3) Construction technology; (4) Coordination among design disciplines; (5) Errors in design drawings; (6) Delay in responding to requests for information; (7) Rework; (8) Lack of incentive scheme; (9) Working overtime; and (10) Construction manager's lack of leadership. The factors explored were classified under the following three primary groups: (1) Management; (2) Technological; (3) Human/labor.

This study has identified the factors that affected on labor productivity within the Libya construction industry. A total of 30 factors were identified in this study, with an identification of factors influencing construction productivity which is based on a careful review of literature and suggestions from local experts in building construction. The factors explored were classified under the following three primary groups: (1) Management; (2) Technological; (3) Human/labor. The results indicate that 3 main top factors negatively affecting labor productivity, which are: (1) Lack of labor supervision; (2) experience and skill of labor, and (3) Construction technology.

The result of the labor experience and skill factor agrees with the fact that the Libyan construction industry suffers from the lack of trained and skilled workers. In the construction industry, construction labor skills and experience should be improved through training programmed in order for the workforce to adapt to policies that are needed to mitigate the influence of unemployment and to leverage excessive local labor which can enhance the construction industry and the overall economy. In this regard, the governmental policy should encourage and pay more attention to formal secondary technical education and learner programs. Also, contractors should provide strong assistance and support regarding the continual training of their labors. In addition, the results can be used as part of further research modeling the interaction relationship between the key factors affecting productivity and improving construction labor productivity in the Libyan construction industry.

\section{References}

[1] Abdul Kadir, M. R., Lee, W. P., Jaafar, M. S., Sapuan, S. M., and Ali, A. AA. A., (2005). "Factors affecting construction labour productivity for Malaysian residential projects." Journal of Structural Survey. 23 (1) 42-54.

[2] Alinaitwe, H. M., Mwakali, J. A., and Hansson, B. (2007). "Factors affecting the productivity of building craftsmen- studies of Uganda." Journal of Civil Engineering and Management. 13 (3) 169-176.

[3] Anu, V., Thomas, J. Sudhakumar, (2014). "Factors influencing construction labour", Journal of Construction in Developing Countries. 19 (1) 53-68.

[4] Attar, A. A., Gupta, A. K., and Desai, D. BD. B. (2012). "A study of various factors affecting labor productivity and methods to improve it", Journal of Mechanical and Civil Engineering. 11-14.

[5] Bekr, G. A Mahamid. (2016). "Study of Significant Factors Affecting Labor Productivity at Construction Sites in Jordan: Site Survey." Journal of Engineering Technology (JET). 4 (1) $92-97$

[6] Durdyev, S. and Mbachu, J. (2011) "On-site labour productivity of New Zealand construction industry: Key constraints and improvement measures." Australasian Journal of Construction Economics and Building. 11 (3) 18-33.

[7] El-Gohary, K. M. and Aziz, R. F. R. F. (2014). "Factors influencing construction labor productivity in Egypt." Journal of Management in Engineering. 30 (1) 1-9.

[8] Enshassi, A., Mohamed, S., Abu Mustafa, Z., and Mayer, P. E. (2007). "Factors affecting labour productivity in building projects in the Gaza Strip." Journal of Civil Engineering and Management. 8 (4) 245-254.

[9] Frefer, A. A., Mahmoud, M., Haleema, H., \& Almamlook, R. (2018). Overview Success Criteria and Critical Success Factors in Project Management. Industrial engineering \& management, 2169-0316.

[10] Alkasisbeh, Maha, Rabia Almamlook, Muna Alkasasbeh, and Muteb Alshammari. Implementation of Six Sigma Tools in Building Construction.

[11] Frefer, A., Almamlook, R. E., \& Suwayd, M. (2017). Productivity Analysis of the General Electric Company of. American Journal of Management Science and Engineering, 2 (6), 192-198.

[12] Hinze, W., (1999). "Construction planning and scheduling", Prentice Hall, New Jersey, USA, 1999. Horner, R. M. W., Talhouni, B. T., and Thomas, H. RH. R., (1989). "Preliminary results of major labour productivity monitoring program." Proceedings of the $3^{\text {rd }}$ Yugoslavian Symposium on Construction Management. Zagreb Univ., Croatia. 18-28.

[13] Jarkas, A. M. (2015) "Factors influencing labour productivity in Bahrain's construction industry." International Journal of Construction Management. 15 (1) 94-108.

[14] Jarkas, A. M., and Bitar, C. GC. G. 2012). "Factors affecting construction labor productivity in Kuwait." Journal of Construction Engineering and Management. 138 (7811-820).

[15] Lema, N. M., and Samson, M. (1995). "Construction of labor productivity modeling.” University of Dar Elsalaam, Tanzania

[16] Lim, E. C., and Alum, J., (1995). "Construction productivity: issues encountered by contractors in Singapore." International Journal of Project Management. 13 (1) 51-58.

[17] Liu, M. and Ballard, G., (2008). "Improving labor productivity through production control", Proceedings of the $6^{\text {th }}$ Annual Conference of International Group for Lean Construction, Manchester, United Kingdom. 657-666. 
[18] Mahamid, I. (2013). "Principal factors impacting labor productivity of public construction projects in Palestine: Contractors' Perspective.", International Journal of Architecture, Engineering and Construction (IJAEC. 2 (3) 194-202.

[19] Makulsawatudom, A., Emsley, M., and Sinthawanarong, K. (2004). "Critical factors influencing construction productivity in Thailand", The Journal of King Mongkut's Institute of Technology, North Bangkok. 14 (3) 1-6.

[20] McTague, B. and Jergeas, G., (2002). "Productivity improvements on Alberta major construction projects"; Construction Productivity Improvement Report / Project evaluation tool, Alberta economic development, Alberta, Canada, 2002.

[21] Olomolaiye, P., Kaming, P., Holt, G., and Harris, F. (1996). "Factors influencing craftsmen's productivity in Indonesia." International Journal of Project Management, 1996, 15 (1) 21-30.

[22] Almamlook, Rabia, et al. "A Simulation Model to Improve Productivity in the Pipe Manufacturing Industry." Journal of Southwest Jiaotong University 55.2 (2020).

[23] Sincich, T. L., Levine, D. M., and Stephan, D. (2002). Practical statistics by example using Microsoft Excel and Minitab, 2nd Ed., Prentice Hall, Upper Saddle River, NJ.
Singh, S. P. (2010), "Factors affecting the productivity of construction operations in the United Arab Emirates", MS thesis, Heriot-Watt University, Edinburgh. [Google Scholar].

[24] Soham, M. and Rajiv, B., (2013). "Critical factors affecting labor productivity in construction projects: case study of South Gujarat region of India." International Journal of Engineering and Advanced Technology. 2 (4) 583-591.

[25] Wachira, L. NL. N (1999) "Labour productivity in the Kenyan construction industry", University of Nairobi, Kenya, 1999.

[26] Wilcox, S., String fellow, B., Harris, R., and Martin, B. (2000). "Management and Productivity." Transportation Research Board, Committee on Management and Productivity, Washington, DC.

[27] YatesYates, J. K. and Guhathakurta, S. (1993) "International labor productivity", Cost Engineering Journal. 35, (1) 15-25.

[28] Zakeri, M., Olomolaiye, P., Holt, G, and Harris, F. (1996). “A survey of constraints on Iranian construction operatives' productivity." Construction Management and Economics. 14 (5), 417-426.

[29] Van Tam, Nguyen, Nguyen Lien Huong, and Nguyen Bao Ngoc. "Factors affecting labour productivity of construction worker on construction site: A case of Hanoi." Journal of Science and Technology in Civil Engineering (STCE)-NUCE 12.5 (2018): 127-138. 